\title{
Study on Teaching of Western Culture under the Background of Economic Belt of the Silk Road
}

\author{
Lizhen Wang ${ }^{1}$ \\ ${ }^{1}$ Xi'an International University, Xi'an, Shaanxi, 710065 \\ 346591653@163.com
}

KEYWORDS: Cultural Strategy Objectives; Western Culture Teaching; Silk Road Economic Belt

\begin{abstract}
The Silk Road is the main link between the ancient and the West, it played an irreplaceable role in the West's dealings. In September 2013, first proposed during President Xi Jinping visit to Kazakhstan Silk Road economic belt-building initiatives, under this background, China urgently needs to build cultural strategic goal to achieve a comprehensive development of the country, therefore, the study of Western culture teaching is particularly important. This paper outlines the basic connotation of the Silk Road Economic Belt, analyzes the significance of the Silk Road Economic Belt under the Background of Western culture teaching, presents the main content of Western culture teaching and specific ways to implement, so as more research Silk Road educators economic zone to provide a reference value.
\end{abstract}

\section{Introduction}

With the rapid development of Chinese economy, China has become the second largest economy in the world, for the construction of the Silk Road economic belt provides a strong foundation. Silk Road economic zone to promote regional development and narrow the gap between China and the West, to strengthen exchanges between Chinese and Western has a huge role. It requires great efforts to build the Silk Road economic belt in order to advance the teaching of Western culture, to achieve Western cultural and educational exchanges and cooperation and promote the development of China's cultural education.

\section{The Basic Purpose of Silk Road Economic Belt}

Ancient Silk Road is an important link between Western exchanges of exchanges between East and West has an important role in promoting. Silk Road connects the Chinese civilization, the Mediterranean civilization and Arab civilization. Generalized Silk Road and Maritime Silk Road into the Silk Road, it is a narrow finger Silk Road. Silk Road overland trade route connecting the Asian continent overland commerce, continental Europe and the African continent, mainly carried out between East and West economic, political, cultural, enter the Central Plains region of production to the Western Region representative silk, porcelain, tea and other items. This channel mainly in the Western Han Dynasty Chang'an as a starting point, approach in the Hexi Corridor to Dunhuang starting point into two north-south roads: Road from Loulan Dunhuang route, round table, Kuqa, Kashgar, crossing the Pamirs west Mediterranean arrival areas along the northern foot of the Kunlun Mountains to the south of Tarim Basin by Da Nanya New Delhi; Road across from Dunhuang to Dali Hai has Conglingxi coast. With the change of time, the Silk Road, the ancient 
Silk Road Economic mentioned Routes and advanced with very different general secretary Xi Jinping, the Silk Road Silk Road Economic Belt is based on the formation of evolved political, economic, cultural exchanges as one of the economic zone.

General Secretary Xi Jinping in the economic belt of the Silk Road Initiative, clearly put forward five basic connotation of the Silk Road Economic Belt policy communication, China Unicom road, unimpeded trade, monetary circulation and popular communication. Communication policy communication means on the basis of mutual recognition, should strengthen communication policies in China and other countries and regions to minimize friction policy exchange between the two sides, and under both common sense, the introduction of a series of economic belt of the Silk Road development of laws and regulations to ensure the smooth development of exchanges between the two sides. China Unicom is under way in existing roads Unicom situation, the strengthening of regional road infrastructure in western China, to enhance road density and the rest of China, the Silk Road Economic Belt to lay the foundation. The smooth flow of trade and money circulation is in the context of economic development strategies, strengthen exchange of trade between China and other countries and regions, enhance trade, and increased trade, we must establish a mutually accepted currency for trade settlement This requires both sides to strengthen docking operations between banks. Popular communication refers to China in the process of building the Silk Road Economic Belt to face the threat of neighboring countries, and China should focus on neighboring countries to provide public resources to achieve harmonious development, harmony and stability to provide a secure Silk Road Economic Belt international environment.

\section{The Meaning of Teaching of Western Culture under the Background of Economic Belt of the Silk Road}

\section{A. Promote Countries Closely, East-West Cultural Heritage}

Ancient Silk Road is an important channel of communication connecting East and West, different countries, different nationalities, cultural exchanges between different religions, trade exchange and harmony create an important bond. In the Silk Road economic vaginal discharge, increasingly close links between the countries, especially the exchanges between China and Central Asian countries among the countries of interdependence, mutual promotion and common development in the areas of politics, economy, culture, etc. more extensive exchanges. Students learn different country's political economic and cultural process, further promote the integration of China and the Central Asian region of the nation, to promote the common development and progress of countries. Silk Road Economic Belt to the East and West together tightly, so that East Fang Hanru civilization, Western civilization, Persian, Greek and Roman civilizations, the South Indian civilization jointly together. In the course of East-West cultural exchanges, cultural exchanges through the Silk Road Economic Belt to implement innovative strategies to achieve Western culture teaching, so that students continue to absorb foreign advanced civilization, thus strengthening the Eastern and Western Culture.

\section{B. Enhance Students' Awareness of Intercultural Communication}

With the good results achieved in the Silk Road economic belt construction, more and more attention to students National Education Cross - cultural communicative competence, the creation of cross-cultural communication courses in the course of practice. In the specific teaching practice, cross-cultural communication consciousness communicators in the communication process on the use of cultural consciousness and sensitivity degree of expression. Teachers will be teaching culture and language teaching in close contact students with the values, moral and thinking patterns so that 
students in the learning process, while their master cultural knowledge, to strengthen his country's cultural understanding. Western culture were teaching under the background of the Silk Road economic belt capable of cross-cultural case studies teaching, teachers guide students to consciously analyze the actual process of thinking, understanding of different cultures while taking advantage of modern information technology to build student interest situations stimulate students multisensory, stimulate students 'thinking, so that students experience in enhancing cultural sensitivity, so as to enhance students' awareness of cross-cultural communication.

\section{Help Students Master the Multicultural}

It proposes to make the Silk Road Economic Belt exchanges and cooperation between China and countries in the region are getting closer, and further promote the development of national culture in the country. At present culture teaching in colleges and universities of the course content and materials design and pay more attention to international standards, to complement existing textbooks cultural content along with some economic areas surrounding countries. Students focus on respect for cultural differences in foreign cultures learning process, research cultural phenomena that exist in different countries values, nationality and religion and so on. Students compare their own culture and other cultures in the process of understanding the differences among the different, and reflect their own cultures and promote mutual, so that the students' ability of open and inclusive cultural formation, based on the basis of objective understanding and mastering each national culture.

\section{The Main Contend of West Culture Teaching}

Western culture teaching purpose is to allow students to compare the major cultural differences and values of China and other Western countries in the learning process, improve students' cultural awareness differences, master the basic knowledge and skills in international cultural communication, improve student learning international culture awareness and the quality of learning, while strengthening their own heritage and innovation of Chinese traditional culture, enhance national self-confidence, to learn the fine tradition of Western culture, so as to promote the comprehensive development of their own.

Western culture teaching content including historical relations and major geographical differences in Western culture, the development process of Western culture, Western culture, language and communication, to compare different values and ways of thinking in the West; Western religious differences. Historical geography of Western culture including learning the knowledge of Western history geographical environment and their impact on Western culture; Development of Western culture main elements of Western culture, learning Greek culture, Indian culture, Roman culture; Western culture, language relationships and communication with the main differences is through learning interrelated Western culture, language and communication between, and then compare it with China, to strengthen students' understanding of different differences in the West; the West is different values under study by a particular historical and cultural conditions of the formation of Western, Chinese traditional culture and values taught at the comparative analysis to help learners to establish the scientific value; Western way of thinking is to enable students to compare different values based on a clear and Western differences in ways of thinking and their advantages and disadvantages, and a good way of thinking in the West are fused into a self-thinking and behavior; and Western religious differences primarily to enable students to understand the religion of the human spirit to build a world generated significant action, understand the different religious ideas in Western civilization in the long process of development formed. 


\section{The Main Method to Conduct West Culture Teaching under Silk Road Economic Belt}

Silk Road in driving economic development zone, the Western culture teaching should be the Silk Road cultural knowledge and teaching content along the country together, in order to achieve a real sense of cultural development, and to further promote the Silk Road Economic Belt. Such as teachers by chance classroom cultural nature and cultural functions and contain the content and scope, with different forms of teaching to teach learners to fully understand and master the different national cultural values and cultural customs. Teachers can conduct various seminars, regularly set different cultural themes in order to build a series of cultural lectures, so that students learn cultural knowledge system. In the background of the Silk Road Economic Belt, Chinese people do not understand the culture of the countries along the Silk Road, it will not narrow the distance between other countries, conducting exchange activities will cause misunderstanding each other's culture is not conducive to deeper cultural exchange, so in Western culture teaching should focus on cultural knowledge to teach and train.

In the teaching process, teachers should enhance the understanding of the true meaning of culture on students and master, requiring teachers and students interactive teaching between different cultures, so that the students in a particular cultural interaction in order to feel the essence of foreign culture clearly. For example, teachers and students can discuss the exchange on the current specific cultural phenomena or cultural event, so that students feel between themselves and teachers to understand different cultures and discuss the exchange of ideas in the process, and make it a cultural awareness of self-criticism. You can also carry out cultural activities such as case studies, different cultures have concerns where a detailed analysis of the conflict between different cultures provide solutions to resolve. Through continuous discussion and exchange, so that students in equal and open platform evolved equality, respect, objectivity cultural attitudes. Therefore, teachers should pay attention to interactive teaching to help students form the corresponding cultural attitudes.

Western culture teaching should focus on practical teaching of economic belt along the Silk Road countries in culture, only allow students to participate in cultural practices in personal experience, gain economic belt along the Silk Road during the formation of the national cultural knowledge and cultural awareness level and mastery, thus enhancing students' knowledge and understanding of Western culture. For example, can be appropriately held Silk Road Economic Belt Cooperation Seminar, led the students regularly participate in the Silk Road Economic Belt Expo. Students participate in volunteer activities, quickly and easily with the Silk Road economic belt along the country's people to interact directly and intuitively understand and acquire cultural knowledge of other countries, to promote students' cultural awareness and enhance cultural competence in communication.

All in all, in the background of the Silk Road economic belt of Western culture teaching, and promoting Western cultural and educational exchanges and cooperation, so as to improve the quality of education in our culture, and further realize the goal of building the Silk Road Economic Belt.

\section{REFERENCE:}

[1] Ding Zhigang. China's Diplomacy in Central Asia under Building "Silk Road Economic Belt" Background [J]. Social Scientists, 2014,09: 13-17.

[2] Zhang Huifeng, Lu Xiaohua, Wang Qinqin. Dissemination of Research under the "Silk Road Economic Belt" Background Central Asia - Second Central Asian Forum of Propagation [J]. International Press, 2015 (07): 168-176. 
[3] Han Xiaohui. Situation and College Students' Intercultural Communication Competence Training Examination of College English Teachers [J]. Foreign Language Research, 2014 (03): 106-110. 